\title{
Andrological Aspects in the Aging Male
}

\author{
W.B. Schill, F.M. Köhn
}

\begin{abstract}
Abstrak
Ditinjau dari segi demografi, bidang andrologi akan semakin dibebani oleh masalah-masalah pria menua, terufama yang berkaitan dengan fertilitas. Walaupun terdapat variasi besar antara individu, umumnya fertilitas pria tetap bertahan sampai usia tua. Akan tetapi peningkatan kejadian mutasi spontan, berarti risiko genetik semakin tinggi bagi anak-anak dengan ayah yang berusia rua. Kadar androgen yang menurun pada usia tua diikuti oleh penurunan aktifitas seksual dan perubahan pada otot dan tulang, yang menimbulkan pertanyaan akan perlunya substitusi hormon.
\end{abstract}

\begin{abstract}
In view of demographic trends, andrology will increasingly be concerned with problems of the aging male, especially with aspects of fertility. While there is considerable interindividual variation, fertility in men usually persists well into old age. However, increased occurrence of spontaneous mutations means a higher genetic risk for children of older fathers. Diminished androgen levels in old age lead to reduced sexual activity and changes in muscles and bones, which raise the question of hormone substitution.
\end{abstract}

Keywords : Aging male, fertility, hormone substitution, genetic risk

Andrology, usually considered to take care of men in their reproductive years who suffer from infertility, has so far neglected the aging male. This is due to the fact that men over 50 years rarely seek help for impaired fertility, but more often consult a doctor for erectile dysfunction. Thus, in contrast to increasing knowledge about the female menopause which terminates the reproductive period in women, knowledge about the aging male has been limited.

There is no doubt that due to the demographic development in the industrialized countries, more consideration will be given in the future to the aging male. In the European Community, for example, the percentage of men above 60 years is currently $15 \%$, whereas it is estimated to be $25 \%$ in the year 2000 . Thus, the higher expectation of life, involving claims for satisfatory living conditions even in old age, will be stimulative to knowledge, diagnostics and therapy of medical problems of the aging male.

Results obtained in women cannot be transferred to men. In contrast to the relatively well-defined aging of

Department of Dermatology and Andrology, Justus Liebig University, Giessen, Germany

${ }^{*} \mathrm{E}_{2}=$ Estradiol the female gonads, indicated by a rapid decline of $E_{2}{ }^{\star}$ during the menopause, the process of aging in the male is retarded and subjected to high individual variations. Nevertheless, old age is accompanied by clinical signs of reduced virility such as decreases in muscle mass and strength, in sexual hair growth and in libido, indicating diminished androgen levels. An age-related decline of androgen secretion and plasma testosterone levels might suggest the necessity of androgen substitution in order to improve an androgen-dependent decrease of virility in old age.

It is the aim of this paper to summarize what is known about the aging male, under the special aspect of andrology.

\section{Fertility status and testicular alterations}

There is a growing interest in aging and its effect on the reproductive potential of men, since an increasing number of couples wish to have children in their late reproductive years when the reproductive system is no longer operating optimally. Fertility in men usually persists well into old age, and a sudden fall in either Leydig cells or seminiferous tubular function does not occur as is seen in menopause. However, a continuous age-dependent decrease of daily sperm production is expected. Similar to other organs, there is a consider- 
able interindividual variation in age-dependent changes of the testes. ${ }^{1}$ One-third of men over 60 and $50 \%$ of those over 80 are completely infertile. Principally, however, spermatogenesis may be retained well into senescence. Children have been fathered by men over 90 years of age. $^{2}$

In a study of 200 patients aged 65 to 93 years, ${ }^{1}$ it is demonstrated that intact spermatogenesis, including the development of mature spermatids, occured in $90 \%$ of the subjects. However, kinetic disorders were observed, such as disturbed spermatogoniogenesis, disturbed meiosis or spermatid malformations, which parallelled a highly significant decrease in daily sperm production. This indicates a gradual decline of fertility with increasing age, although alterations in sperm quality may be minimal. Most frequently, decreases in motility and in the percentage of spermatozoa with normal morphology are demonstrated. ${ }^{3,4}$

Concerning the age of the male partner and its influence on fertility, several studies have shown that a significant drop of fertility is only observed when the female partner is over 39 years, whereas the age of the male partner does not play a significant role in couples with infertility.

Concerning tubular alterations with advancing age, the seminiferous tubules gradually become atrophic as a result of decreasing germinal epithelium. These changes do not affect the entire testes in like manner, but may initially occur focally. Conspicious is an increased desquamation of partly immature germ cells into the lumen of the seminiferous tubules. The basal layers of the germinal epithelium are disorganized as well. Gradually increasing quantitative and qualitative disturbances of spermatogenesis can also be observed by TEM $^{* *}$. In 1988, Holstein, Roosen-Runge and Schirren studied the pathology of human spermatogenesis, including the aging testis, and characterized age-dependent alterations in the seminiferous tubules. In summary, an increased number of severe pathological changes in the seminiferous tubules were observed, ranging from morphologically altered spermatogonia to the occurrence of spermatogenic arrest, formation of megalospermatocytes, giant spermatocytic cells, acrosomal malformation as well as anomalies of spermatid nuclei and tail, without following a typical pattern. ${ }^{5}$

\footnotetext{
** TEM = Transmission Electron Microscopy
}

In addition, macrophages are frequently observed in the tubuli seminiferi of epididymides of old men. Since numerous spermatozoa are often incorporated, they are also called spermatophages. Other typical age-dependent defects of the seminiferous tubular structures include diverticula with evagination of the germinal tissue into the interstitium. The structure is filled with spermatocytes I and Sertoli cells, but no lumen is present. The lamina propria shows only one layer of myofibroblasts. Diverticula are observed in up to $80 \%$ of testicular biopsies in old men. ${ }^{1}$

Sertoli cell are apparently affected as well, including the formation of large vacuoles. Their lipid content is elevated up to giant lipid inclusions, because they increasingly phagocytize degenerated germ cells. AItered Sertoli cell function will lead to increased FSH secretion. In addition, serum inhibin levels in elderly men are lower then those in young people, ${ }^{6}$ supporting a decline in Sertoli cell function with aging. At the same time, the tunica propria shows fibrosis (tubular sclerosis). This process may lead to tubular hyalinization.

To compensate for the reduced synthetic activity of the Leydig cells, GnRH and $\mathrm{LH}$ are increasingly released via the negative feed-back mechanism of the pituitarygondal axis, finally resulting in an increase in size (hyperplasia) of the Leydig cells. The number of Leydig cells declines with advancing age. While about 700 million Leydig cells are present in a 20 -year-old man, this number decreases by 6 to 7 million per year during the further process of aging. ${ }^{7}$ Thus, at the age of 80 years, about 200 million Leydig cells remain to be active.

In old age, lymphocytic and plasmacytic infiltrates are observed in the peritubular tissue, which might be due to immunological processes resulting from degenerated germinal epithelium. The rete testis is often dilated.

\section{Genetic risks in children of old fathers}

Controversy exists regarding the relationship between increased paternal age and the incidence of chromosome anomalies. Referring to potential genetic risks, the American Association of Tissue Banks has established an upper age limit of 40 years for semen donors; the limit set by the American Fertility Society is 50 years. ${ }^{8}$ However, the results of earlier studies demonstrating an increased occurrence of trisomy 21 (Down syndrome) in children of father over the age of 55 was not confirmed by later investigations. Thus, no 
increased risk of numerical chromosomal anomalies in children of old fathers could be demonstrated! On the other hand, structural chromosomal anomalies seem to be more frequent in spermtozoa of older men. Martin and Rademaker observed the highest incidence of structural chromosome anomalies in men ober 44 years, with approximately $13 \%$ of spermatozoa showing chromosomal damage. ${ }^{9}$ So far, however, there are no evidence from studies of live newborns of prenatally diagnosed fetuses that older fathers have an increased frequency of offspring with de novo (non-inherited) structural chromosomal anomalies. ${ }^{8}$

Genetic mutations result from errors in DNA replication. They can be passed on to the next generation as a single gene defect. Therefore, the effect of advanced paternal age has been extensively studies in association with new cases of single gene defects. It was suspected that increased paternal age can lead to autosomal dominant mutations. This theory is now widely accepted, and increased paternal age has been associated with a variety of autosomal dominant diseases (e.g. achondroplasia, aniridia, hemophilia $A$, Lesch Nyhan syndrome, Marfan syndrome, neurofibromatosis, polycystic kidney disease, poliposis coli, progeria).

The risk for fathers over 40 years to have a child with an autosomal dominant mutation is comparable with the risk of trisomy 21 for a child whose mother is aged 35 to 40 years. Friedman established risk estimates for increased paternal age and its contributions to new autosomal dominant mutations. As demonstrated, a higher risk with increasing paternal age can be seen. ${ }^{10}$ Friedman suggested that approximately one third of children with autosomal dominant mutations were fathered by men over the age of 40 . Lian and coworkers found that paternal age over 40 years was related to a $20 \%$ increased occurrence of birth defects. $^{11}$

In summary, based on the available data, paternal ages over 45 years must be viewed cautiously with regard to potential genetic risks. There is only one argument in favor of advanced paternal age: Examinations of the literature and particularly studies in high school boys by Dietz-Helmers have indicated that increased age of fathers and particularly of paternal grandfathers correlates well with a higher intelligence of the descendants. $^{12}$

\section{Endocrinological alterations}

Changing sex hormone concentrations in aging men are due to functional disturbances of the Leydig cells, an impaired feed-back mechanism of the pituitarygonadal axis, and reduced bioavailability of hormones. At this point, the significant contributions by Vermeulen and his coworkers from Belgium during the last decade have to be acknowledged; Vermeulen has been a pioneer in the endocrinology of the aging man.

Decreased sex hormone concentrations become manifest as early as the fifth to sixth decade of life. However, due to great interindividual variability, testosterone levels in older men may well be within the normal range for younger men. An age- associated decrease of testosterone becomes statistically relevant only after the seventh decade of life. ${ }^{13}$ With advancing age there is a progressive decline in the synthesis of testosterone by Leydig cells, accompanied by an increase of $\mathrm{LH}$ levels.

Several investigators have clearly demonstrated that reduced testosterone levels are of primarily testicular origin. Leydig cells seem to be less responsive to stimulation by LH which is apparently not due to a reduction in $\mathrm{LH}$ receptors on Leydig cells. ${ }^{14}$

Decreased responsiveness to $\mathrm{LH}$ is probably caused by a diminished reserve of testosterone in the Leydig cells, which is parallel to a significant decrease of the total steroid content in the testes of elderly men. In addition, a shift in testicular androgen biosynthesis has been reported by Vermeulen, favoring synthesis and secretion of $\Delta 4$ steroids over $\Delta 5$ steroids in old age, $\Delta 5$ steroids being the precursors of testosterone in the biosynthetic chain. The primarily testicular origin of decreased androgen secretion in senescence is further supported by the reduction of Leydig cells in elderly men. There have also been reports of diminished testicular perfusion in aging testes, with a decrease in the number of capillaries pointing to a reduced oxygen supply in testicular tissue of old men. 13

Apart from the primarily testicular origin of decreased plasma androgen levels, additional alterations occur at the hypothalamopituitary level: Despite elevated LH plasma concentrations, which partly compensate for reduced synthetic activity of the Leydig cells, high amplitude LH pulses from the pituitary gland are significantly less frequent, whereas the amplitude of $\mathrm{LH}$ pulses remains unchanged. ${ }^{15}$

In addition, although $\mathrm{GnRH}$ stimulation reveals a large secretory reserve capacity of the gonadotrophs, LH levels are not high enough to normalize free testosterone levels. ${ }^{16}$ 
Bremner and coworkers ${ }^{17}$ as well as Vermeulen ${ }^{18}$ observed disappearance of the circadian testosterone rhythm in elderly men, while serum androgen levels in young men demonstrated nyctohemeral variations with high testosterone concentrations in the early morning. This is probably the consequence of a decreased $\mathrm{LH}$ rhythm, pointing towards an alteration at the hypothalamopituitary level.

There are also indications of an increased sensitivity of the hypothalamo-pituitary axis to sex hormone feedback. Other experiments by Vermeulen investigated the sensitivity of gonadotrophs, particularly of $\mathrm{LH}$, to the feedback effect of plasma sex hormone levels. ${ }^{13}$ A greater sensitivity of the gonadotrophs to the sex hormone feedback was demonstrated. It is suggested that the changes in the hypothalamo-pituitary function in elderly men might be secondary to changes in neurotransmitter or neuromodulator systems such as hypothalamic dopamine, noradrenaline or opioid concentrations. $^{19,20}$

Coming back to the testicular level, a decline in the intratesticular testosterone concentrations cannot be avoided despite increased serum LH levels. Reduced intratubular testosterone concentrations, however, may affect spermatogenesis, which, together with agedependent processes in the germ cells, results in elevated serum FSH levels. Furthermore, there is evidence that LH and FSH molecules may undergo age-related changes, resulting in reduced bioactivity. In addition, stress may play a role in age-associated changes of plasma testosterone levels. As far as testicular function is concerned, elderly men are less sensitive to stress than are young adults.

Vermeulen ${ }^{18}$ showed that hypoglycemia induces a significant decline in testosterone levels in younger men, whereas in elderly men this stress is without any effect on testosterone concentrations. Interestingly, other environmental factors such as diet, moderate physical activity of life style had no effect on plasma testosterone levels. 13

Because of their hydrophobic nature, steroid hormones such as testosterone are bound to plasma proteins e.g. albumin and sex hormone binding globulin (SHBG). Only $2 \%$ of testosterone are unbound and thus biologically active. After the age of 70, SHBG levels in the serum are increased, resulting in declined concentrations of free testosterone. ${ }^{2 P}$ Thus, in addition to decreased synthesis of testosterone, increased binding capacity of the testosterone binding globulin determines the availability of biologically active free testosterone molecules.

Elevated SHBG concentrations are caused by an increase of free estradiol. Serum estrogen levels in elderly men are higher as a result of stimulated aromatization of androgens, especially in the peripheral fatty tissue which is increased during aging. Declining free testosterone levels in plasma are accompanied by a decrease in tissue testosterone and/or its active metabolite DHT. Thus, Deslypere and Vermeulen demonstrated a highly significant decline in both testosterone and DHT concentrations in different tissues with age. ${ }^{22,23}$

In elderly men, an alteration of testosterone metabolism characterized by a decreased ratio of 5 alpha over 5 beta metabolites, in parallel with a decline of 5 alpha reductase activity was also found with increasing age. $^{18}$

\section{Male clinuacteric?}

The term "climacterium virile" was created in 1939 by Wermer who described men at or beyond the fifth decade of life who suffered from vegetative complaints and a number of symptoms such as impaired memory, lack of concentration, tiredness, nervousness, and lowered resistance to stress. ${ }^{24}$ In analogy to the female climacteric, a sudden reduction in plasma testosterone levels and rapid senile involution of the testes were initially thought to be responsible. Later studies, however, showed that hormonal changes and morphological processes of aging in the male gonads were significantly different from those in aging women. A gradual decline in testosterone levels is observed only in old age. The germinal epithelium shows age-related changes, but there is great interindividual variability. Functioning germ cells are found even in men over 80 years. Therefore, the existence of a male climacteric is more than questionable. Doubtful is at least if any relation between climacterium virile and changes in the plasma testosterone levels exists. Improvement of subjective symptoms by administration of androgen derivatives is not contradictory to this, but may reflect psychotropic effects of androgens. ${ }^{25}$ None of the symptoms attributed to the male climacteric has been demonstrated to be of statistically significant prevalence in men at the fifth or sixth decade of life.

In summary, while there is evidence of "climacteric complaints" in the male, these do not occur as frequent- 
ly and inevitably as in women and are rather of psychosociological origin. ${ }^{26,27}$ Therefore, the frequently used synonym "midlife crisis" appears to be more appropriate than "male climacteric". Recently, the term PADAM (partial androgen deficiency of aging men) was introduced by Gooren, ${ }^{28}$ which may be another attempt to characterize the problem of aging men.

\section{Question of a possible hormonal supplementation in old age}

As discussed before, total testosterone concentrations are lowered in men over 60 years, without, however, falling below the average values observed in healthy adult men. Therefore, testosterone supplementation is considered a useful therapy for aging men. However, there is scanty information about whether androgen supplementation in older man might be beneficial, such as leading to improved bone density or muscle mass and strength, or whether potential benefits might be outweighed by negative effects on lipid profiles, hematological parameters, or the prostate. In a doubleblind, placebo controlled crossover study, Tenover and coworkers investigated the effect of testosterone enanthate $(100 \mathrm{mg} /$ week $)$ in a small group of healthy men aged 57 to 76 years for a treatment period of 3 months. ${ }^{6}$ Injections of testosterone enanthate resulted in elevated concentrations of both total testosterone and free testosterone in all men, and increased libido or aggressiveness in business transactions in some men. In others, a general improvement in sense of wellbeing were reported. All men showed an increase in weight, but not in body fat. Urinary excretion of hydroxyproline decreased, indicating delayed bone absorption. Positive effects of testosterone enanthate on hematological parameters and lipid metabolism were observed. Concerning the prostate, testosterone injections did not lead to significant changes in prostate size and residual urine; however, a significant increase in prostate-specific antigen (PSA) was observed. $30 \%$ of the men showed elevated levels of PSA even at 3 months after cessation of therapy.

In principle, testosterone supplementation in old patients may produce the following side-effects:

(1) changes in fat metabolism

(possible changes of LDL/HDL ratio) = cardiovas cular risk?

(2) stimulating effect on erythropoiesis with a risk of polycythemia;

(3) more rapid development of benign prostatic hyperplasia;

(4) stimulation of subclinical prostatic carcinoma.

In any case, when testosterone supplementation is considered in old age, these men should be carefully screened and followed periodically throughout the testosterone therapy to avoid any risk of a more rapid development or exacerbation of pre-existing BPH or prostatic cancer. Androgen therapy in aging men is still controversial, and large prospective studies on beneficial and undesired effects of testosterone administration aimed at life quality are urgently needed. So far, androgen therapy in aging men can only be recommended for substitution of manifest testosterone deficiency.

Another therapeutic attempt, which is still experimental, is the administration of growth hormone (GH). Total GH secretion declines with advanding age, resulting in lower serum insulin- like growth factor (IGF) I levels. ${ }^{29}$ Reduced GH secretion is thought to be related to senile osteoporosis, muscular atrophy and sleep disturbances. First placebo-controlled studies in small patient groups, including old men and those deficient in insulin- like growth factor I, showed that IGF-I levels, bone density and body weight increased during therapy, while body fat was reduce. ${ }^{30} \mathrm{At}$ present, however, it is too early to draw any conclusions as to whether this treatment will significantly contribute to physical and psychological improvement of processes that are involved in senescence.

In conclusion, current knowledge about problems of the aging man is scanty. Many questions are still open. However, due to the demographic development, increased research in the male it is mandatory to meet the requirements of the aging population.

\section{REFERENCES}

1. Holstein AF. Spermatogenese im Alter - ein Grenzgebiet zwischen normaler und pathologischer Anatomie. Urologe (A) 1986,25:130-7.

2. Silber SJ. Effects of age on male fertility. Semin Reprod Endocrinol 1991,9(3):241-8.

3. Nieschlag E, Lammers U, Freischem CW, Langer K, Wickings EJ. Reproductive functions in young fathers and grandfathers. J Clin Endocrinol Metab 1982,55:676-81.

4. Schwartz D, Mayaux M, Spira A, Moscato ML, Jouannet P, Czyglik F et al. Semen characteristics as a function of age in 833 fertile men. Fertil Steril 1983;39:530-5.

5. Holstein AF, Roosen-Runge EC, Schirren C. Illustrated pathology of human spermatogenesis. Grosse, Berlin, 1988. 
6. Tenover JS, Dahl KD, Vale WW, Rivier JE, Bremner WJ. Hormonal responses to a potent gonadotropin hormonereleasing hormone antagonist in normal elderly men. J Clin Endocrinol Metab 1990,71:881-8.

7. Naeves WB, Johnson L, Porter JC, Parker CR, Petty CS. Leydig cells numbers, daily sperm production and serum gonadotropin levels in aging men. $J$ Clin Endocrinol 1984,59:756-63.

8. Bordson BL, Leonardo YS. The appropriate upper age limit for semen donors: a review of the genetic effects of paternal age. Fertil Steril 1991,56:397-401.

9. Martin RH, Rademaker AW. The effect of age on the frequency of sperm chromosomal abnormalities in normal men. Am J Hum Genet 1987,41:484-92.

10. Friedman JM. Genetic disease in the offspring of older fathers. Obstet Gynecol 1981;57:745-9.

11. Lian ZH, Zack MM, Erickson JD. Paternal age and the occurrence of birth defects. Am J Hum Genet 1986,39:64860.

12. Dietz-Helmers A. On correlation between the generation age of fathers and grandfathers and the intelligence of the descendants. Experientia 1974,30:567-9.

13. Vermeulen A. Alteration of Leydig cell function and its mechanism in the aging male. In: Holstein AF, Leidenberger F, Hölzer KH, Bettendorf G (Hrsg) Carl Schirren Symposium: Advances in Andrology. Diesbach, Berlin, $1988 \mathrm{~S}$ 82-5.

14. Hartmann SH, Talbart GB. Reproductive aging. In: Finch CE, Hanflicks L (eds) Handbook of the biology of aging, 2nd ed. van Nostrand Reinhold, New York, 1985, pp 457-510.

15. Winters SJ, Troen P. Episodic luteinizing hormone (LH) secretion and the response of LH and follicle-stimulating hormone in aged men: Evidence for coexistent primary testicular insufficiency and an impairment in gonadotropin secretion. J Clin Endocrinol Metab 1982,55:560-5.

16. Wide L. Median charge and charge heterogeneity of human pituitary FSH, LH and TSH: II. Relationship to sex and age. Acta Endocrinol (Copenh) 1985,109:190-7.

17. Bremner WJ, Vitiello MV, Prinz PN. Loss of circadian rhythmicity in blood testosterone levels with aging in normal men. J Clin Endocrinol Metab 1983,56:1278-81.

18. Vermeulen A. Androgens and male senescence. In: Nieschlag E, Behre HM (eds) Testosterone. Springer, Berlin-Heidelberg, 1990 pp 261-76.
19. Peng MT. Changes in hormone uptake and receptors in the hypothalamus during aging. In Meites J (ed) Neuroendocrinology of aging. Plenum Press, New York 1983, pp 61-71.

20. Simpkins JW. Changes in hypothalamic hypophysiotropic hormones and neurotransmitters during aging. In: Meites J (ed) Neuroendocrinolgy of aging. Plenum Press, New York, 1983, pp 41-61.

21. Baker HWG, Hudson B. Changes in the pituitary-testicular axis with age. In : de Kretser BM, Burger HG, Hudson B (eds) The pituitary and testis. Clinical and experimental studies. Monographs on Endocrinology 25. Springer, Berlin-Hamburg-New York, 1983, pp 71-82.

22. Deslypere JP, Vermeulen A. Aging and tissue androgens. J Clin Endocrinol Metab 1981, 53:430-4.

23. Deslypere JP, Vermeulen A. Influence of age on steroid concentration in skin and striated muscle in women and in cardiac muscle and lung tissue in men. J Clin Endocrinol Metab 1985,60:648-53.

24. Wermer AA. The male climacteric. JAMA 1939, 119: 1441-3.

25. Kaiser FE, Kies N, Maas G, Schmid H, Beach RC, Bormacher K, Horrmann WM, Richle E. The measurement of the psychotropic effects of an androgen in the aging male with psychovegetative symptomatology : a controlled double blind study mesterolone versus placebo. Progr Neurol Psychopharmacol 1978,2:505-15.

26. Featherstone M, Hepworth M. The male menopause: Lifestyle and sexuality. Maturitas 1985,7:235-46.

27. Greeve J. Das sogenannte Klimakterium virile. In: Greeve J, Bichler J (Hrsg) Sexuallormone und altern. VOD, Eppelheim, S 91-93, 1987.

28. Gooren L. Testosterone: its role in sexual functioning and ageing. 3rd International Symposium "New Perspectives of. Andrology in Human Reproduction" September 19-24, 1994

29. Hoffmann AR, Liebermann JA, Ceda GP. Growth hormone therapy in the elderly: implications for the aging brain. Psychoneuroendocrinology 1992,17(4):327-33.

30. Rudman D, Feller AG, Nagraj HS, Gergans GA, Lalitha Py, Goldberg AF, Schlenker RA, Cohn L, Rudman IW, Mattson DE. Effects of human growth hormone in men over 60 years old. N Engl J Med 1990,323:1-6. 